September; copious spore-discharge continued for about two months, the adjoining areas of the trunk becoming dusted over with Ganoderma spores. Gradually, the lower surface turned pinkish and finally brownish with stoppage of spore-discharge by the following December. In the course of these three months the porous area on the upper face of the cut-out sector became gradually covered with the typical laccate crust-growth of the upper surface (Fig. 2, above) and its lower surface was at the same time flanked over with hymenial growth from two sides (Fig. 2, below). A section of the present upper face of the sector showed the typical thick-walled palisade hyphæ in close cluster with a number of brown shot-out spores here and there under the new crust (Fig. 3).

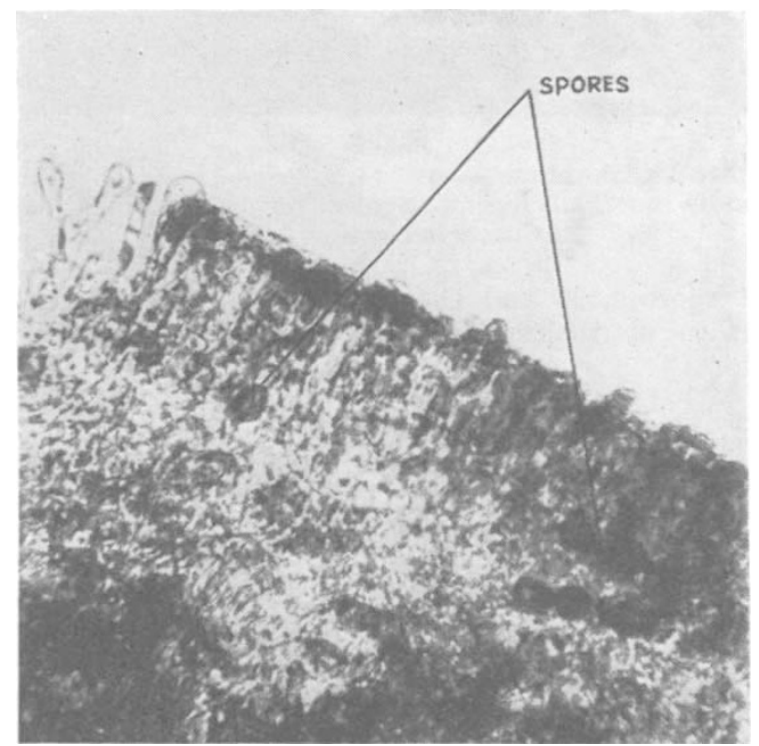

Fig. 3.

Photomicrograph of a section OF THE NEWLY DEVELOPED CRUST SHOWING THICK-WALLED PALISADELIKE HYPHA AND A NUMBER OF BROWN SPORES AT A LOWER LEVEL.

(Leitz objective No. 7. Eyepiece No. 75.)

This experiment lends support to the view recently put forward by Némec ${ }^{1}$ and Lohwag ${ }^{2}$ that the polarity in cases of some Polypores is convertible.

In another sporophore a narrow triangular gap was caused by removing a thin slice from about the middle; it was found that the gap was gradually bridged over in the course of about two months by numerous young hyphæ growing from two sides all over, except the outer thick crust.

For the photographs of Figs. 1 and $2 I$ am grateful to Dr. K. P. Biswas, superintendent of the Royal Botanical Gardens, Calcutta, and to Dr. D. B. Chatterjee.

S. R. Bose.

Botanical Laboratory,

Carmichael Medical College, Calcutta.

March 1.

${ }^{1}$ Nærmec, B., Bull. Internat, Acad. Tscheque, C. Math. Nat. et. Med., 36 (1935)

2 Lohwag, K., Ann. Mycol., 37, 169 (1939).

\section{Gynospore Formation in Sequoia sempervirens}

IN spite of the intrinsic interest of the redwoods and mammoth trees of California their gametophytes and embryogeny were poorly known until recently. Lawson's ${ }^{1}$ account of Sequoia sempervirens was unsatisfactory and incomplete and only a cursory reference by Arnoldi ${ }^{2}$ was available for $S$. gigantea. Looby and $\mathrm{I}^{3}$, however, described recently fertilization and proembryo formation in S. gigantea for the first time and also extended and amended Lawson's ${ }^{1}$ account of these features in the redwood; while Buchholz ${ }^{4}$ afterwards dealt with the embryogeny in both types. It is clear from the results recorded that development in these two trees is so different that they can no longer be retained in the one genus.

Except for the doubtful account by Lawson ${ }^{1}$ of gynospore formation in S. sempervirens, no accurate description has yet been given of the early origin and development of the gynospores in either case. Collections have now been made to cover these phases and so complete the full life-history; and these phases also are quite different in the two plants. Details will be published in due course, but it seemed advisable to put on immediate record the unique condition found in S. sempervirens. A number of gynospore mother cells are commonly formed, of which up to eight (or more ?) may form tetrads. The members of a spore tetrad may form a linear row, but more frequently the gynospores are in compact groups of four, arranged symmetrically in one plane or in a. tetrahedron, the whole being surrounded by a definite tapetum, usually of one cell layer. A transverse section of the ovule at this stage resembles a young pollen sac in a remarkable way.

In no other conifer is the sporangial nature of the nucellus so clearly shown. As these tetrads are only a little larger than the pollen tetrads this condition in the redwood is a further cogent argument against the continued use of the terms mega- and micro-spore for the spores of the conifers, with all that the use of these terms commonly implies.

J. DoYle.

Botany Department,

University College,

Dublin.

May 3.

${ }^{1}$ Lawson, Ann. Bot., 18, 1 (1904).

${ }^{2}$ Arnoldi, Bull. Soc. Nat. Moscon, 14, 449 (1900).

${ }^{3}$ Looby and Doyle, Sci. Proc. Roy. Dub. Soc., 21, 457 (1937).

- Buchholz, Amer. J. Bot., 26, 93 (1939).

\section{Destruction of Cabbage White Butterflies by Birds}

THE enormous numbers of 'Large Cabbage Whites' (Pieris brassicce (L.)) which entered England last summer were preyed upon very frequently by birds, and this Department received many dismembered wings picked up in gardens, etc. The offspring of these immigrants have been much in evidence this month, and have also been destroyed in large numbers by birds.

Mr. A. H. Hamm, A.L.S., has kindly collected dismembered wings in a churchyard in east Oxford, and examination gives the following result: 